DOI 10.4467/25439561KSR.21.005.14416

\author{
MareK MelnyK (D) https://orcid.org/0000-0002-7583-5956 \\ Uniwersytet Warmińsko-Mazurski \\ Olsztyn
}

\title{
POJEDNANIE POLSKO-UKRAIŃSKIE. DIALOG PAMIĘCI
}

\author{
POLISH-UKRAINIAN RECONCILIATION. \\ THE DIALOGUE OF MEMORY
}

\begin{abstract}
Streszczenie
W artykule dokonano analizy wpływu Kościoła katolickiego na proces dialogu i pojednania polsko-ukraińskiego. Wskazano na kwestię chrześcijańskiego uniwersalizmu odwołującego się do elementów łączących oba narody oraz implikującego postawy zmierzające do porozumienia Polaków i Ukraińców. Skoncentrowano się także na poszukiwaniu i rekonstrukcji źródeł działań o charakterze religijnym, inicjujących dialog i proces przebaczenia między stroną polską i ukraińską. Podkreślono znaczenie i uniwersalną rolę tradycji religijnych w przemianach stosunków polsko-ukraińskich.
\end{abstract}

\begin{abstract}
The article analyses the impact of the Catholic Church on the process of Polish-Ukrainian dialogue and reconciliation. It highlights the concept of Christian universalism referring to the elements that connect both nations and implying attitudes aimed at reaching understanding between Poles and Ukrainians. The author focuses also on finding and reconstructing the sources of religious activities that initiate dialogue and the process of reconciliation between Polish and Ukrainian party. The importance and universal role of religious traditions in the transformation of Polish-Ukrainian relations is strongly emphasised.
\end{abstract}


Słowa kluczowe: Kościół katolicki, pojednanie polsko-ukraińskie, dialog pamięci, przebaczenie

Keywords: the Catholic Church, Polish-Ukrainian reconciliation, dialogue of memory, forgiveness

We współczesnej kulturze dialog pamięci zbiorowych, dostarczających jednostce tożsamości społecznej poprzez przynależność do małej ojczyzny, narodu, uniwersalnej religii, kręgu cywilizacyjnego, ideologii, ruchów fundamentalistycznych, partii politycznych, jest jednym z najważniejszych i najtrudniejszych problemów ${ }^{1}$. O tym, że ma on w naszej epoce ogromną wartość doskonale świadczy proces pojednania polsko-ukraińskiego. Jego promotorzy dokonują konfrontacji kolektywnego myślenia dwóch wspólnot narodowych. Czynią to jednak po to, by przezwyciężyć pamięć o konfliktach w XX wieku (Orlęta, walki UPA i AK, krwawe mordy na Polakach na Wołyniu, akcja „Wisła”), która często uniemożliwia dialog i zasklepia w rozpamiętywaniu i apoteozie własnej martyrologii. Spotykają się tutaj dwie przeciwstawne pamięci ludzkiej krzywdy. Mimo to zwolennicy pojednania obu narodów dążą do przezwyciężenia tego właśnie paradygmatu. Przez ponad trzydzieści lat wolna Polska i niepodległa Ukraina zrobiły wiele dla procesu pojednania i budowania realnego partnerstwa. Politycy i duchowni spotykali się, składali ważne, mądre i potrzebne deklaracje. Okazało się jednak, że proces ten nie dotknął najistotniejszych pokładów świadomości historycznej i wykreowanych mitologii narodowych ${ }^{2}$.

Celem niniejszego artykułu jest ukazanie pojednania polsko-ukraińskiego jako próby dialogu pamięci zbiorowych realizowanego na gruncie religijnym. Można dokonać tego poprzez zaprezentowanie podstawowych dokumentów religijnych poświęconych dialogowi oraz pojednaniu; wskazanie najważniejszych wydarzeń o charakterze masowym, takich jak spotkania modlitewne, uroczyste celebracje sakramentu Eucharystii w obrządku łacińskim i greckokatolickim, pielgrzymki do miejsc „znaczących" dla obu narodów o charakterze religijnym, jak np. Częstochowa w Polsce i Zarwanycia na Ukrainie; analizę homilii hierarchów kościelnych np. Jana Pawła II, kardynałów Glempa, Huzara; przedstawienie i omówienie nagród i wyróżnień mają-

${ }^{1}$ Zob. M.S. Archer, Kultura i sprawczość. Miejsce kultury w teorii społecznej, thum. P. Tomek, Warszawa, Narodowe Centrum Kultury, 2019; Mosty nadziei. Jagiellońskie inspiracje dialogu międzykulturowego, red. L. Korporowicz, P. Plichta, Kraków, Biblioteka Jagiellońska, 2016; O wolność i sprawiedliwość. Chrześcijańska Europa między wiarq i rewolucja, red. U. Cierniak, N. Morawiec, A. Bańczyk, Częstochowa, Instytut Filologii Obcych Uniwersytetu Humanistyczno-Przyrodniczego im. Jana Długosza w Częstochowie, Polskie Towarzystwo Historyczne, Oddział w Częstochowie, 2018.

${ }^{2}$ Zob. Nie jesteśmy ukrainofilami. Polska myśl polityczna wobec Ukraińców i Ukrainy. Antologia tekstów, red. P. Kowal, J. Ołdakowski, M. Zuchniak, Wrocław, Kolegium Europy Wchodniej im. J. Nowakowskiego, 2008. 
cych na celu uhonorowanie ludzi zaangażowanych w dialog miedzy obu narodami, np. nagrody pojednania polsko-ukraińskiego ustanowionej w 2001 roku; wskazanie różnego rodzaju działań symbolicznych, takich jak odnawianie lub fundowanie pomników upamiętniających wybitne postacie z życia obu narodów, odnawianie cmentarzy wojennych, budowa cmentarzy ofiar konfliktów między obu narodami w XX wieku podczas I i II wojny światowej. Wymienione przez nas przykłady działań pojednawczych między obu narodami tworzą wyraźny proces dialogu odmiennych pamięci historycznych. Jest on ukierunkowany na przełamywanie negatywnych stereotypów, przezwyciężanie konfliktów w sferze symbolicznej poprzez odwoływanie się do chrześcijańskiej aksjologii.

Spośród wymienionych działań przedstawimy deklaracje o pojednaniu między obu narodami sformułowane przez hierarchów katolickich obu narodów. Deklaracje to swoisty rodzaj dokumentów. Mają one charakter oficjalnych wypowiedzi osób pełniących funkcje urzędowe, przywódcze. Są to zwykle politycy, liderzy organizacji społecznych, duchowni. Tworzą je zatem przedstawiciele elit społecznych. Są to często wypowiedzi formułowane ex cathedra. Charakter tego rodzaju dokumentów wymaga specyficznej metody badań ${ }^{3}$. Z pewnością należy odczytać to, co jest w nich „podskórne”, ukryte, wyrażone nie expressis verbis oraz oddzielać w nich to, co jest pragnieniem skierowanym ku przyszłości od tego, co jest stanem teraźniejszym. Należy zatem podchodzić do tego zjawiska in statu nascendi, tak aby uchwycić choćby zarys i ruch myśli ludzi pragnących urzeczywistnić ideę pojednania polskoukraińskiego. Warto również potrudzić się by porównać polsko-ukraińskie dążenia pojednawcze z podobnymi wysiłkami innych narodów, Niemców i Francuzów, Niemców i Polaków, Chorwatów i Serbów.

\section{Dialog polsko-ukraiński w 1. połowie XX wieku}

Zanim przejdziemy do zasadniczego tematu, należy wspomnieć o wcześniejszych podobnych inicjatywach ${ }^{4}$. Są one bardzo różnorodne. Wydaje się, że drogi pojednania między obu narodami poszukiwał Zygmunt Szczęsny Feliński, postulu-

${ }^{3}$ Zob. M. Melnyk, Problem badań nad dialogiem i pojednaniem polsko-ukraińskim, [w:] W cieniu akcji Wista, red. M. Melnyk, Olsztyn, Instytut Nauk Politycznych Uniwersytetu Warmińsko-Mazurskiego, 2008, ss. 99-120.

${ }^{4}$ Zob. M. Melnyk, Rola prezydenta Rzeczypospolitej Polskiej Aleksandra Kwaśniewskiego oraz hierarchów Kościoła greckokatolickiego w pojednaniu i dialogu polsko-ukraińskim. Zarys problematyki, „Biuletyn Ukrainoznawczy” 2003, nr 9, ss. 83-98; Idem, Pojednanie polsko-ukraińskie. Deklaracja Kościołów katolickich Polski i Ukrainy z 19 IV 2005 r., „Przegląd Powszechny” 2005, nr 12, ss. 87-102; Idem, Rola Kościoła greckokatolickiego w dialogu i pojednaniu polsko-ukraińskim po 2001 roku, [w:] Polityka i mniejszości narodowe na pograniczach, red. M. Giedrojć, M. Mieczkowska, J. Mieczkowski, Szczecin, Wydawnictwo Naukowe Uniwersytetu Szczecińskiego, 2005, ss. 145-156. 
jący wzajemne rozumienie i wymianę dóbr duchowych między Polakami a Rusinami w Galicji ${ }^{5}$. Próbą dialogu między obu narodami były rozmowy i porozumienie zawarte w Galicji w 1914 roku między Michałem Bobrzyńskim a greckokatolickim arcybiskupem Lwowa Andrzejem Szeptyckim ${ }^{6}$. Do następnej próby dialogu doszło podczas walk polsko-ukraińskich we Lwowie po zakończeniu I wojny światowej. Przykładem tamtych inicjatyw jest list Szeptyckiego do lwowskiego arcybiskupa obrządku łacińskiego Józefa Bilczewskiego z 1919 roku, w którym czytamy:

„Nieszczęsna wojna przynosi to niestety z soba, że mamy obaj nie raz przyczyny ubolewania nad jej skutkami i że musimy raz w raz, to jeden to drugi, interwencją każdy po swojej stronie te skutki łagodzić. Czyńmy to - zachowując przynajmniej między sobą chrześcijańską miłość i jedność"’

Do następnej próby do pojednania obu narodów na gruncie religijnym doszło w latach 1922-1925 ${ }^{8}$. Andrzej Szeptycki propagował dialog polsko-ukraiński również w okresie późniejszym. Przykładem tego jest jego wypowiedź z 1935 roku, opublikowana w „Biuletynie Polsko-Ukraińskim”:

„Obydwa społeczeństwa są już zmęczone nieznośnym stanem, trwającym tyle lat. Nie łudzę się jednak, że jest tu ogromne pole pracy nad usunięciem wzajemnej nieufności, wzajemnej nieszczerości, żalów i niestety ogromnie dużo słusznych pretensji. Jest jeszcze olbrzymie pole pracy dla zrobienia tego, co musi być zrobione dla dobra stosunków obydwu wielkich narodów, które z woli Opatrzności żyją i żyć muszą obok siebie i z sobą"”.

W okresie międzywojennym dialog między obu narodami próbował inicjować Jan Henryk Józefski, dążący do poprawy stosunków między Ukraińcami i Polakami na terenie Wołynia ${ }^{10}$.

${ }^{5}$ Zob. G. Bachanek, Elementy idei słowiańskości Zygmunta Szczęsnego Felińskiego a myśl Jana Pawła II, „Warszawskie Studia Teologiczne” 2016, nr 3, ss. 218-231.

${ }^{6}$ Zob. W.A. Serczyk, Historia Ukrainy, Wrocław, Warszawa, Kraków, Zakład Narodowy im. Ossolińskich, 1990, ss. 318-319; S. Stępień, Wysitki Polaków i Ukraińców na rzecz wzajemnego porozumienia w latach 1918-1939, „Warszawskie Zeszyty Ukrainoznawcze” 1994, z. 2, ss. 96-104; M. Mróz, Katolicyzm na pograniczu. Kościót katolicki wobec kwestii ukraińskiej i białoruskiej w Polsce w latach 1918-1925, Toruń, Wydawnictwo Adam Marszałek, 2003, ss. 124-125.

${ }^{7}$ O. Hajowa, Nauka społeczna metropolity Andrzeja Szeptyckiego w świetle materiałów archiwalnych, [w:] Polska - Ukraina. 1000 lat sqsiedztwa, t. 4, red. S. Stępień, Przemyśl, Instytut Południowo-Wschodni w Przemyślu, 1998, s. 279.

${ }^{8}$ Zob. M. Mróz, Katolicyzm na pograniczu..., op.cit., ss. 125-128.

${ }_{9}^{9}$ Metropolita Andrzej Szeptycki. Pisma wybrane, red. M.H. Szeptycka, M. Skórka, Kraków, Społeczny Instytut Wydawniczy Znak, 2000, s. 21.

${ }^{10}$ Zob. J. Kęsik, Zaufany komendanta. Biogram polityczny Jana Henryka Józefskiego 1892-1981, Wrocław, Uniwersytet Wrocławski, 1995, ss. 110-152. 


\section{Millennium chrztu Rusi Kijowskiej}

Porządkujący przegląd deklaracji pojednawczych między obu narodami rozpoczniemy od dokumentów, których powstanie jest ściśle związane z jubileuszem tysiąclecia chrztu Ukrainy ${ }^{11}$. Pierwszy z nich pojawił się podczas spotkania Polskich i Ukraińskich biskupów w Rzymie 8 października 1987 roku w Papieskim Kolegium Polskim w Rzymie. Było to wystąpienie kardynała Józefa Glempa, które funkcjonuje pod tytułem Przemówienie podczas spotkania w Kolegium Polskim. W istocie była to deklaracja o przebaczeniu i pojednaniu polsko-ukraińskim ${ }^{12}$. Prymas Polski w swym przemówieniu poruszył kilka problemów. Najpierw zaznaczył, że spotkanie biskupów obu obrządków odbywa się podczas światowego synodu biskupów oraz w przededniu uroczystości tysiąclecia chrześcijaństwa na ziemiach ukraińskich. Nakreślił również perspektywę organizacji uroczystości milenijnych chrztu Rusi w Polsce.

„Ufam, że w przyszłym roku Bóg pozwoli nam razem na Jasnej Górze włączyć się w Wasze «Te Deum» dziękczynienia Bogu za 1000 lat łaski chrztu, za lata wierności, za oczyszczające lata cierpień, za lata nadziei lepszej przyszłości. Matce Bożej zawierzamy nasze i wasze sprawy. Zawierzamy Jej sprawy trudne, aby prowadziła nas do Chrystusa razem z naszymi rodakami”"13.

Po tym przeszedł do problemu pojednania. Co ciekawe, kardynał Glemp mówiąc stanowczo o bezwarunkowym pojednaniu, wcale nie pominął problemu zapomnienia doznanych krzywd. Wyszedł właśnie od nich! Lecz po to, żeby żądać zmiany myślenia o nich:

„Nie chcemy poruszać historii, w której na pierwszy plan wybijają się sprawy bolesne. Taka jest tendencja patrzenia na nasze wspólne sprawy. Może kiedyś odkryjemy w naszej historii dobre karty, bo takie były. [...] Dziś jednak przygniata nas jakby nawyk narzekań, uprzedzeń, oraz wspomnienia łez, a także krwi”14.

Glemp podkreślił, że dzieje chrześcijan to ciągła walka ze złem, będącego skutkiem sprzeniewierzenia się Ewangelii. W jego ujęciu grzech jednostki ma wymiar społeczny i historyczny. Dlatego stanowczo odrzucił pokusę porównywania, absolu-

${ }^{11}$ Zob. M. Bobrownicka, R. Łużny, Karol Wojtyła - Jan Pawet II w kregu spraw słowiańskich, [w:] Dzieło chrystianizacji Rusi Kijowskiej i jego konsekwencje w kulturze Europy, red. R. Łużny, Lublin, Redakcja Wydawnictw Katolickiego Uniwersytetu Lubelskiego, 1988, ss. 351-383.

${ }^{12}$ Zob. J. Glemp, Przemówienie podczas spotkania w Kolegium Polskim, „Znak” 1988, nr 4, ss. 29-31.

${ }^{13}$ Ibidem, s. 31.

${ }^{14}$ Ibidem. 
tyzowania polskich i ukraińskich krzywd oraz cierpień. Patrzył na nie z perspektywy millennium chrztu Polski i Ukrainy. Miał chyba świadomość, że ta perspektywa powoduje, że wszelkie bilansowanie krzywd będzie niesprawiedliwe. Decyduje bowiem o tym czas, w którym Polacy lub Ukraińcy będą sporządzać swoje rachunki krzywd. Prymas wyraźnie to powiedział:

„Nie wolno nam podejmować licytacji, kto komu więcej krzywd wyrządził. Do niczego to nie doprowadzi. Szczególnie my, duchowni, winniśmy wiedzieć, że gojących się ran nie wolno rozdrapywać. Pomyślmy, że mógł być ktoś trzeci, kto nas wzajemnie podburzał, by wygrać własne interesy"15.

Warto jeszcze zwrócić uwagę, że Glemp nie wspomniał o pojednaniu polskoniemieckim jako wzorcu pojednania polsko-ukraińskiego. Podobny dokument ujrzał światło dzienne 17 października w Kolegium Ukraińskim św. Jozafata w Rzymie, gdzie biskupi greckokatoliccy - w ramach kontynuacji spotkania, które odbyło się 8 października - gościli biskupów rzymskokatolickich. Wówczas to Arcybiskup Większy Lwowa, kardynał Myroslav Ljubachivs'kyj, zwracając się do kardynała Józefa Glempa, wygłosił specjalne przemówienie, którego najważniejszym elementem była deklaracja pojednania polsko-ukraińskiego. Co ciekawe ten fragment zdaje się być lustrzanym odbiciem wypowiedzi Glempa z dnia 8 października, ponieważ Lubacivs'kyj w imieniu episkopatu greckokatolickiego powiedział:

„Jesteśmy wdzięczni Tobie i Twoim Współbraciom w biskupstwie za wyrażoną gotowość zapomnienia wszystkich bolących urazów i tego, co nasze narody tak często dzieliło w ciągu ich historii, a co nieraz było od nich całkowicie niezależne"'16.

Dalej dodał:

„Dzisiejsze spotkanie ma wyraz szczególnej wagi i radości, gdyż dzisiaj możemy wspólnie modlić się i odbyć braterską rozmowę u progu wielkiego jubileuszu - Tysiąclecia Chrztu Narodu Ukraińskiego. [...] również i my - hierarchia Ukraińskiej Katolickiej Cerkwi - wyciaggamy braterską dłoń do Braci Polaków na znak pojednania, przebaczenia i miłości” ${ }^{17}$.

Lubacivs'kyj podziękował następnie za zaproszenie na uroczystości jubileuszowych na Jasnej Górze:

${ }^{15}$ Ibidem, ss. 29-30.

${ }^{16}$ M. Lubacziwśkyj, Przemówienie podczas spotkania w Kolegium św. Jozafata, „Znak” 1988, nr 4, ss. 33-34.

${ }^{17}$ Ibidem, s. 33. 
„Przy tej okazji dziękuję serdecznie Księdzu Prymasowi za zaproszenie nas, Ukraińskiej Hierarchii, do Częstochowy, by tam u stóp Najświętszej Maryi Panny, wspólnie z ukraińskim Narodem zamieszkującym na ziemiach polskich i całym Narodem i Kościołem w Polsce i Jego Hierarchią, przeżyć Wielki Jubileusz Chrztu naszego Narodu. Cudowna Ikona Maryi Panny, zanim przybyła do Częstochowy, w ciągu setek lat odbywała swoją macierzyńską wędrówkę po rozległych ziemiach Ukrainy. Jej zatroskane, zbolałe oczy i dzisiaj jeszcze są zwrócone na swoje dzieci. Akurat dziś, 17 października, w sobotę, gdy my modliliśmy się w kaplicy, tam w Częstochowie modli się Pielgrzymka Młodzieży Ukraińskiej z całej Polski, by błagać swą Matkę o błogosławieństwo i wolność dla swego Kościoła i Narodu"18.

Kardynał Glemp w swej odpowiedzi na przemówienie Arcybiskupa Większego Lwowa zwrócił uwagę rolę Częstochowy:

„Gdy mówię o tym, że wrócimy do ołtarzy, mam na myśli, przede wszystkim te ołtarze, przy których dokona się jubileuszowa celebra Eucharystii dziękująca Bogu za 1000-lecie chrześcijaństwa Rusi - myślimy o tym ołtarzu na Jasnej Górze. Miejsce to ma swoją wielką wymowę, zwłaszcza gdy się pomyśli, że w swojej Ojczyźnie tych ołtarzy mają tak mało. Niektórzy uczeni twierdzą, że cudowna Ikona Jasnogórska mogła być namalowana we Włoszech, może w Pizie lub we Florencji, a później przez Andegawenów dotarła na Węgry, skąd została przewieziona do Polski. Jednakże tradycja nieprzerwanie utrzymuje, że obraz był namalowany w Palestynie, potem przebywał w Bizancjum (tak jak Całun Turyński), a następnie został przywieziony na Ruś, by w roku 1382 znaleźć się na Jasnej Górze. Na Ruś wiara chrześcijańska przyszła także z Bizancjum. Święty Włodzimierz przejął stamtąd Ewangelię i obrządek, przyjął także cześć ku Matce Najświętszej, która głęboko zakorzeniła się w narodzie ruskim. Jeżeli Matka Boża Jasnogórska przyszła z Bliskiego Wschodu do Środkowej Europy - do Polski, a droga Maryi jest drogą wytyczoną przez Opatrzność Bożą, to dziś trzeba, aby ludy z pogranicza Wschodu i Zachodu przychodziły do Niej. Rzeczywiście wiele ludów przychodzi w pielgrzymkach do Jasnogórskiego Sanktuarium, zaś najbliżej położone ludy słowiańskie mają w dotarciu do Niej największe trudności. Maryja, w jakimkolwiek byłaby czczona obrazie, zawsze jest Matką Kościoła i naszą Matką"19.

I dopiero po ukazaniu integrującej roli Częstochowy jako ośrodka kultu maryjnego, łączącego chrześcijan dwóch kręgów kulturowych łacińskiego i bizantyńskiego, w tym i Polaków i Ukraińców, Prymas Polski nawiązując do fragmentu z Ewangelii według św. Mateusza (5, 23-24), powiedział:

\footnotetext{
${ }^{18}$ Ibidem, s. 34.

${ }^{19}$ J. Glemp, Przemówienie podczas spotkania w Kolegium św. Jozafata, „Znak” 1988, nr 4, s. 37.
} 
„Jesteśmy winowajcami wobec Boga, bo jesteśmy grzeszni, jesteśmy winowajcami wobec braci, bo za mało $\mathrm{w}$ nas miłości. Jesteśmy winowajcami wobec Was, Bracia Ukraińcy, bo nie umieliśmy nauki wynikającej z Chrztu świętego wprowadzić w życie. [...] Mamy winy jedni wobec drugich. A gdzie są winy, tam trzeba mówić: Odpuść nam nasze winy, jako i my odpuszczamy"20.

Jak widzimy, biskupi przygotowując się do obchodów milenium chrztu RusiUkrainy, nie nawiązywali wprost do modelu religijnego wypracowanego w trakcie pojednania polsko-niemieckiego. Zarysowali również pewien system wartości owego procesu pojednawczego. W jego trakcie miały być realizowane następujące wartości: „,braterska rozmowa”, „pojednanie”, ,przebaczenie” i „miłość”. Gdy je zestawimy razem suponują one jakiś wcześniejszy konflikt, obcość, nienawiść. Są to antywartości, które zaistniały między obu narodami w przeszłości. Świętowanie misterium chrztu z 988 roku zmusiło biskupów do przeciwstawienia się im i przezwyciężenia ich $^{21}$. W tym miejscu należy przypomnieć, że zgodnie z deklaracjami obu episkopatów w 1988 roku w Częstochowie doszło do uroczystości jubileuszu tysiąclecia chrztu świętego księcia Włodzimierza22.

\section{Jan Paweł II}

Przytaczając katolickie deklaracje o pojednaniu polsko-ukraińskim, należy wspomnieć o roli Jana Pawła II w kształtowaniu podstaw teorii i praktyki przebaczenia. Inspirowane przez Ojca Świętego pojednanie polsko-ukraińskie było ,wkomponowane" w szerszy kontekst spraw trudnych dotyczących nie tylko tych dwóch narodów. Papież bowiem proponował ,wszystkim” drogę pojednania i przebaczenia ${ }^{23}$. W deklaracje pojednawcze szczególnie obfitowała wizyta Jana Pawła II na Ukrainie. Dnia 26 czerwca 2001 roku we Lwowie w czasie homilii wygłoszonej podczas mszy świętej, na której ogłoszono beatyfikację arcybiskupa Józefa Bilczewskiego oraz księdza Zygmunta Gorazdowskiego, papież wyraźnie nawiązał do pojednania polsko-ukraińskiego. Pragnął, aby ta beatyfikacja była interpretowana w tym kontekście. Papież zwrócił uwagę na fakt, że już sama konsekracja J. Bilczewskiego miał wymiar pojednawczy:

${ }^{20}$ Ibidem.

${ }^{21}$ Zob. M. Łesiów, M. Melnyk, O Ukrainie. Prawie wszystko!?, Olsztyn, Katedra Aksjologicznych Podstaw Edukacji. Uniwersytet Warmińsko-Mazurski, 2011, ss. 450.

${ }^{22}$ Zob. M. Melnyk, Millennium chrztu Rusi Kijowskiej w procesie pojednania polsko-ukraińskiego, [w:] Polacy i Ukraincy. Komunikacja - dialog - pojednanie, red. M. Melnyk, Kraków, Collegium Columbinum, 2021, ss. 99-113.

${ }^{23}$ Zob. Jan Paweł II, O przebaczeniu i pojednaniu, Kraków, Wydawnictwo M, 2000, ss. 16-28. 
„Ta beatyfikacja jest także dla mnie źródłem szczególnej radości. Błogosławiony Józef Bilczewski wpisuje się w linię mojej sukcesji apostolskiej. To on bowiem konsekrował arcybiskupa Bolesława Twardowskiego, ten zaś z kolei wyświęcił biskupa Eugeniusza Baziaka, z którego rąk otrzymałem święcenia biskupie. Tak więc dzisiaj ja również zyskuję nowego, szczególnego patrona. Dziękuję Bogu za ten przedziwny dar. Jest jeszcze jedna okoliczność, której nie można przeoczyć przy tej okazji. Błogosławiony arcybiskup Bilczewski został konsekrowany przez kardynała Jana Puzynę, biskupa krakowskiego. Obok niego stali jako współkonsekrujący błogosławiony Józef Sebastian Pelczar, biskup przemyski, i sługa Boży Andrzej Szeptycki, arcybiskup greckokatolicki. Czyż nie było to wydarzenie niezwykłe? Duch Święty sprawił wówczas, że spotkali się trzej wielcy Pasterze, z których dwaj zostali już ogłoszeni błogosławionymi, a trzeci - jak Bóg da - dostąpi tego w przyszłości. Ta ziemia prawdziwie zasłużyła na to, aby ujrzeć ich razem, gdy dokonywali uroczystego aktu ustanowienia kolejnego następcy Apostołów. Zasłużyła, aby zobaczyć ich zjednoczonych. Ich jedność pozostaje znakiem i wezwaniem dla wiernych należących do owczarni każdego z nich, którzy za ich przykładem mają budować komunię, zagrożoną przez pamięć o wydarzeniach z przeszłości i przez uprzedzenia wyrosłe z nacjonalizmu"24.

Jak widzimy, Jan Paweł II jeszcze raz proponował spojrzenie w przeszłość stosunków polsko-ukraińskich. Czynił to po to, by szukać w niej przykładów nie „trudnych problemów", ale działań pojednawczych będących inspiracją dla rozwijanych współcześnie inicjatyw, mających na celu dialog i pojednanie. Takim znakiem była dla niego konsekracja Bilczewskiego, która został uwieńczona jego beatyfikacją. Dopiero patrząc z tej perspektywy, papież wezwał do pojednania polsko-ukraińskiego. Była to zatem również zachęta do dążenia do świętości. Papież podkreślił, że jedynie ludzie świeci są zdolni do pojednania. Niejako w imieniu Bilczewskiego, Pelczara, Puzyny, Szeptyckiego powiedział:

„Dzisiaj, gdy wielbimy Boga za to, że ci Jego słudzy okazali tak nieugiętą wierność Ewangelii, odczuwamy głęboką wewnętrzną potrzebę uznania różnych przejawów niewierności ewangelicznym nakazom, jakich nierzadko dopuszczali się chrześcijanie pochodzenia zarówno polskiego, jak i ukraińskiego, zamieszkujący te ziemie. Czas już oderwać się od bolesnej przeszłości! Chrześcijanie obydwu narodów muszą iść razem w imię jedynego Chrystusa, ku jedynemu Ojcu, prowadzeni przez tego samego Ducha, który jest źródłem i zasadą jedności. Niech przebaczenie - udzielone i uzyskane - rozleje się niczym dobroczynny balsam w każdym sercu. Niech dzięki oczyszczeniu pamięci historycznej wszyscy gotowi będą stawiać wyżej to, co jednoczy, niż to, co dzieli, aby razem budować przyszłość opartą na wzajemnym szacunku, braterskiej współpracy

\footnotetext{
${ }^{24}$ Jan Paweł II, Przyjmijcie duchowe przesłanie waszych błogosławionych, [w:] https://opoka.org. pl/biblioteka/W/WP/jan_pawel_ii/homilie/lwow_beatyfikacja_26062001.html, [dostęp: 27.09.2021].
} 
i autentycznej solidarności. Dzisiaj arcybiskup Józef Bilczewski i jego towarzysze biskup Pelczar i arcybiskup Szeptycki wzywają was: trwajcie w jedności! ${ }^{25}$ "

Ostatniego dnia pielgrzymki, 27 czerwca we Lwowie, podczas Liturgii Eucharystii w obrządku greckokatolickim z udziałem 1,2 miliona wiernych, kardynał Lubomyr Huzar wygłosił deklarację ekspiacyjną. W obliczu papieża i w imieniu grekokatolików prosił:

„Za nich wszystkich przed tobą Ojcze Święty, chcę prosić Boga o wybaczenie, jak też chcemy przebaczyć wszystkim, którzy nas krzywdzili. Chcemy wymazać wszystkie krzywdy i nienawiść między nami, abyśmy pojednani mogli razem wstąpić w nowe stulecie" 26 .

Nawiązując do słów Huzara o pojednaniu, Jan Paweł II powiedział:

„[...] Ta ziemia galicyjska, która w ciagu historii była świadkiem wzrostu Ukraińskiego Kościoła Greckokatolickiego, została usłana, jak mawiał niezapomniany metropolita Josyf Slipyj, «górami trupów i rzekami krwi». [...] W ciągu ostatnich wieków nagromadziło się zbyt wiele stereotypowych sposobów myślenia, zbyt wiele wzajemnych uraz i zbyt wiele nietolerancji. Jedynym sposobem oczyszczenie drogi jest zapomnienie przeszłości, prośba o wzajemne przebaczenie sobie zadanych i otrzymanych ran, i bezgraniczna ufność w odnowieńcze działanie Ducha Świętego. [...] Niechaj na wasze rany wyleje Bóg oliwę miłosierdzia i pociechy"27.

\section{Posłania o pojednaniu polsko-ukraińskim z dnia 5 maja 2003 roku}

W naszym przeglądzie nie możemy pominąc posłania o pojednaniu polsko-ukraińskim z dnia 5 maja 2003 roku autorstwa kardynała Lubomyra Huzara ${ }^{28}$. W dokumencie tym odnajdujemy zdefiniowanie relacji polsko-ukraińskich. Huzar przestawił je jako coś normalnego: ,Toteż tak, jak to się często zdarza między sąsiadami, działo się również i między nami - jednaliśmy się i pomagaliśmy sobie wzajemnie, kłóciliśmy się, a nieraz byliśmy wrogami [...]"29. Tę przeszłość taką, jaka

\footnotetext{
${ }^{25}$ Ibidem.

${ }^{26}$ Ibidem.

${ }^{27}$ Jan Paweł II, Chrystus droga, prawda i życiem. Pielgrzymka Ojca Świętego na Ukrainę 23-27 czerwca 2001, Kraków, Wydawnictwo M, 2001, ss. 127-128.

${ }^{28}$ Zob. L. Huzar, List pasterski biskupów metropolii kijowsko-halickiej Ukraińskiego Kościoła Greckokatolickiego do braci i sióstr sasiadujacych ze sobq narodów ukraińskiego i polskiego, Lwów 5 maja 2003 r., „Перемиські Архиєпархіяльні Відомості” 2017, nr 23, ss. 191-195.

${ }^{29}$ Ibidem, s. 191.
} 
była należy zaakceptować. Należy jednak patrzeć na nią w świetle chrześcijańskiego objawienia: „Historii nie można zmienić, ponownie napisać, ani zanegować. [...] należałoby ją przynieść przed ołtarz Miłosierdzia Bożego i przekazać historykom $[\ldots]^{\prime 30}$. Ta teologiczna perspektywa nakazywała Huzarowi swoisty chrześcijański racjonalizm w relacjach obu narodów.

„Sam zdrowy rozsądek podpowiada nam, że dla naszego sąsiedztwa nie ma alternatywy. Należymy do jednego geopolitycznego obszaru Europy środkowowschodniej, która ma wspólne interesy polityczne, ekonomiczne i społeczne. [...] Obecnie, w obu naszych krajach zostały uczynione kroki w kierunku budowania demokratycznych społeczeństw obywatelskich. W środowiskach intelektualnych po obu stronach granicy panuje przekonanie, iż bez wolnej Ukrainy nie będzie wolnej Polski i vice versa"’31.

Dopiero po tym racjonalnym i zdroworozsądkowym oczyszczeniu myślenia o sobie wzajem, Huzar wezwał do przebaczenia tego, co złe w historii obu narodów.

„Każdego dnia powtarzamy w Modlitwie Pańskiej: «Ojcze nasz... odpuść nam nasze winy, jak i my odpuszczamy naszym winowajcom», słuchamy słowa Bożego: «A kiedy stajecie do modlitwy, przebaczcie, jeśli macie co przeciwko komuś, aby także Ojciec wasz, który jest w niebie, przebaczył wam wykroczenia wasze. Bo jeżeli wy nie przebaczycie, to i Ojciec wasz, który jest w niebie, nie przebaczy wam przewinień waszych» (Mk 11,25-26). Oznacza to, że mamy sobie przebaczyć krzywdy doznane w naszej wspólnej historii”’32.

Jak widać, akt przebaczenia w jego rozumieniu ma charakter wyłącznie religijny. Jest tutaj wyraźnie zaznaczony ewangeliczny porządek działań pojednawczych. Składa się on z kilku etapów. Najpierw uświadamiamy sobie własną niedoskonałość. Następnie prosimy o przebaczenie Boga własnych win. Uznajemy swoje zło i winę. Potem prosimy o przebaczanie ludzi. Dopiero wówczas jesteśmy gotowi do przebaczenia i przebaczamy. Aby wzmocnić swoje pojednawcze wezwanie Huzar odwołał się do przywoływanej już deklaracji z 1987 roku.

„Piętnaście lat temu, [...] Eminencje kardynał Myrosław Lubacziwski i Prymas Józef Glemp - w duchu wiary w imieniu Episkopatów i narodów wysłowili deklarację o polsko-ukraińskim przebaczeniu, których treść można ująć w słowach: «Wybaczamy i prosimy o wybaczenie». Profetyczny akt światłych mężów naszych kościołów nie został jednak do dnia dzisiejszego w pełni zrealizowany. Winniśmy go rozpatrywać na nowo,

\footnotetext{
${ }^{30}$ Ibidem.

${ }^{31}$ Ibidem, s. 193.

${ }^{32}$ Ibidem.
} 
jako nasze wspólne zadanie i zachętę do poszukiwania właściwych rozwiązań. Wzajemne przebaczenie jest i będzie pierwszym krokiem" ${ }^{\text {"33. }}$

Huzar zaraz potem przestrzegł Polaków i Ukraińców, by nie zmarnowali szansy, jaką jest możliwość urzeczywistnienia autentycznego pokoju między obu narodami. Odwołał się tutaj ponownie do głęboko racjonalnych argumentów: „Bez wzajemnego pojednania nasze narody nie mają i nie będą miały w przyszłości perspektyw rozwoju zarówno na płaszczyźnie religijnej jak i politycznej” ${ }^{34}$. Radził również, by uzbroić się w cierpliwość:

„W naszych warunkach potrzebny jest na to czas, gdyż chodzi o odwrócenie biegu historii. Przez wiele lat szliśmy w błędnym kierunku wzajemnego oddalania się od siebie, dzisiaj zaś potrzebny jest powrót na właściwą drogę ku sobie. Proces pojednania wymaga określonego programu. Który winniśmy wspólnie wypracować i zrealizować”35.

Kardynał zaprosił elity polityczne do włączenia się w dzieło dialogu i pojednania:

„Liczymy na poparcie elit politycznych obu narodów, na współpracę hierarchii i wiernych poszczególnych Kościołów i organizacji religijnych, a także wszystkich ludzi dobrej woli, gdyż chodzi nie o wąską pojętą sprawę konfesyjną, lecz o ogólnonarodową kwestię szczególnej wagi”’36.

\section{0. rocznica tragicznych wydarzeń „,wołyńskich”}

Następną deklaracją pojednawczą jest dokument, który powstał w kontekście obchodów 60. rocznicy tragicznych wydarzeń „wołyńskich” w 1943 roku. W przeddzień uroczystości, które odbyły się 11 lipca 2003 roku w Pawliwce na Ukrainie, Jan Paweł II napisał list do kardynałów, Józefa Glempa, Mariana Jaworskiego i Lubomyra Huzara $^{37}$, w którym zwraca się do nich jak ojciec do dzieci - „Umiłowani synowie bratnich Narodów Ukrainy i Polski" ${ }^{38}$, nakazując pojednanie. W jego przekonaniu bowiem tego dnia „odbędą się oficjalne obchody pojednania ukraińsko-polskiego”. Następnie papież przedstawił własną interpretację wołyńskich wydarzeń:

\footnotetext{
${ }^{33}$ Ibidem.

${ }^{34}$ Ibidem, s. 195.

${ }^{35}$ Ibidem.

${ }^{36}$ Ibidem,

${ }^{37}$ Zob. Jan Paweł II, List z okazji 60. rocznicy tragicznych wydarzeń na Wołyniu, „Biuletnyn Ukrainoznawczy" 2003, nr 9, ss. 9-10.

${ }^{38}$ Ibidem, s. 9.
} 
„W zawierusze drugiej wojny światowej, gdy pilniejsza powinna być potrzeba solidarności i wzajemnej pomocy, mroczne działanie zła zatruło serca, a oręż doprowadził do rozlewu niewinnej krwi" ${ }^{39}$.

Po czym odwołuje się do teraźniejszości:

„Teraz, w sześćdziesiąt lat od tamtych smutnych wydarzeń, w sercach większości Polaków i Ukraińców utwierdza się coraz bardziej potrzeba głębokiego rachunku sumienia. Odczuwa się konieczność pojednania, które pozwoliłoby spojrzeć na teraźniejszość i przyszłość w nowym duchu. To skłania mnie do wdzięczności wobec Boga razem z tymi, którzy w zadumie i w modlitwie wspominają wszystkie ofiary tamtych aktów przemocy" ${ }^{\prime 4}$.

Papież nakazywał interpretować to, co się stało w 1943 roku, w perspektywie nowego milenium chrześcijaństwa:

„Nowe tysiąclecie, w które niedawno wkroczyliśmy, wymaga, aby Ukraińcy i Polacy nie pozostawali zniewoleni swymi smutnymi wspomnieniami przeszłości. Rozważając minione wydarzenia w nowej perspektywie i podejmując się budowania lepszej przyszłości dla wszystkich, niech spojrzą na siebie nawzajem wzrokiem pojednania. Skoro Bóg przebaczył nam w Chrystusie, trzeba, aby wierzący umieli przebaczać sobie nawzajem doznane krzywdy i prosić o przebaczenie własnych uchybień, i w ten sposób przyczyniać się do budowania świata, w którym respektuje się życie, sprawiedliwość, zgodę i pokój. Ponadto chrześcijanie, wiedząc, że Bóg «dla nas grzechem uczynił Tego, który nie znał grzechu» (2 Kor 5, 21), wezwani są, by uznać błędy przeszłości, aby obudzić własne sumienia wobec obecnych kompromisów i otworzyć serca na autentyczne, trwałe nawrócenie" ${ }^{\text {41 }}$.

Patrząc z perspektywy nowego tysiąclecia chrześcijaństwa, wzywał do przebaczenia:

„Kościół w sposób uroczysty i ze świadomością tego wszystkiego, co zaszło w przeszłości, prosił wobec świata o przebaczenie win swoich synów, przebaczając równocześnie wszystkim, którzy wyrządzili mu różnorakie krzywdy. Pragnął przez to oczyścić pamięć ze smutnych wydarzeń, z wszelkiego poczucia urazy i odwetu, aby pokrzepiony i ufny rozpoczął na nowo dzieło budowania cywilizacji miłości”42.

\footnotetext{
${ }^{39}$ Ibidem.

${ }^{40}$ Ibidem, s. 10.

${ }^{41}$ Ibidem.

${ }^{42}$ Ibidem.
} 
Papież zarysował następnie zasady aksjologiczne pedagogiki pojednania obu narodów:

„Jest to tym pilniejsze, gdy rozważa się potrzebę wychowania młodych pokoleń w duchu pojednania i budowania przyszłości bez uwarunkowań historii, nawarstwionej nieufności, bez uprzedzeń i przemocy. [...] Wyrażam radość, że wspólnoty chrześcijańskie Ukrainy i Polski podjęły się zorganizowania tych obchodów, by przyczynić się do zabliźnienia i uleczenia ran przeszłości. Zachęcam oba bratnie Narody, by niezmiennie i wytrwale dążyły do poszukiwania współpracy i pokoju. Przesyłam serdeczne pozdrowienia dla całego Episkopatu, Duchowieństwa oraz Wiernych obydwóch krajów; przekazuję wyrazy szacunku dla Panów Prezydentów i władz świeckich, a za ich pośrednictwem dla Narodów Polski i Ukrainy, które są zawsze obecne w moim sercu i modlitwie, życząc ustawicznego postępu w budowaniu zgody i pokoju. Tym życzeniom towarzyszy moje specjalne Błogosławieństwo Apostolskie, którego udzielam wszystkim uczestnikom uroczystości”"

Swoistą odpowiedzią na wezwanie papieskie była homilia biskupa polowego Wojska Polskiego Leszka Sławoja Głódzia. Zarysował w niej antywartości, które doprowadziły do mordów w 1943 roku $^{44}$ :

„Nie byłoby tych mogił, gdyby przed sześćdziesięciu laty nie zdeptano prawa miłości i przykazania: Nie zabijaj! O przestrzeganie tego przykazania upominał się wówczas metropolita greckokatolicki Lwowa Andrzej Szeptycki, lecz nie został posłuchany. Nie byłoby tej mogiły, gdyby nie zaślepienie, gdyby nie pycha, gdyby nie zgubne przekonanie, że przyszłość narodu można budować na prawie siły i przemocy. A także to przekonanie, że naród jest wartością większą niż Boże prawa, niż porządek sumienia, niż chrześcijańska etyka. Naród nie jest wartością wyższą niż prawo Boże. Przykazanie miłości bliźniego dotyczy nie tylko swoich, ale także ludzi innych narodów i wyznań, a nawet nieprzyjaciół" ${ }^{\prime 5}$.

Biskup polowy wskazał na wartości, które mają być realizowane w procesie pojednania. W jego przekonaniu mają one zastąpić wcześniejszy fałsz, który towarzyszył interpretacji tego, co stało się na ziemi wołyńskiej 60 lat wcześniej. Biskup tak o tym mówił:

\footnotetext{
${ }^{43}$ Ibidem.

${ }^{44}$ Zob. L.S. Głódź, Kazanie wygłoszone przez bp. polowego WP Sławoja Leszka Głódzia podczas Mszy Świętej odprawionej w Pawliwce w intencji Polaków pomordowanych na Wołyniu, „Biuletyn Ukrainoznawczy" 2003, nr 9, ss. 116-118.

${ }^{45}$ Ibidem, s. 117.
} 
„Czyniono wysiłki, aby dramat Wołynia usunąć ze świadomości powojennych generacji, a niekiedy przedstawiać w krzywym zwierciadle, czynić z kata ofiarę, zamykać oczy na zbrodnię ludobójstwa. Nie zbuduje się niczego dobrego na przemilczeniach, półprawdach, fałszach, manipulowaniu historią. Tylko prawda, choćby tragiczna, jak ta, może być podstawą do budowania lepszej przyszłości. Musimy podjąć i my Polacy i Wy Ukraińcy wspólny trud, wspólny wysiłek, aby ocalić i utrwalić pamięć o tym tragicznym epizodzie naszej historii. Uczynić to w imię sprawiedliwości i zadośćuczynienia wobec tych tysięcy męczenników Wołynia. Tylko taka postawa jest godna obywatela nowego tysiąclecia, świata bez granic, jednoczącej się Europy i prawdziwego chrześcijanina" ${ }^{46}$.

\section{List biskupów z dnia 19-26 czerwca 2005 roku}

Następną deklaracją, którą będziemy analizować jest List biskupów greckokatolickich Ukrainy i rzymskokatolickich Polski z okazji aktu wzajemnego przebaczenia i pojednania ${ }^{47}$, ogłoszony w dniach 19-26 czerwca 2005 roku w Warszawie i Lwowie przez arcybiskupa Józefa Michalika i kardynała Lubomyra Huzara. Dokument ten przeniknięty jest ewangeliczną ideą przebaczenia. Już pierwsze zdania tego posłania odwołują się do najstarszych fragmentów Nowego Testamentu:

„W Roku Eucharystii podejmujemy wezwanie Świętego Pawła: «W imię Chrystusa prosimy: pojednajcie się z Bogiem!» (2 Kor 5, 21). Uczestniczymy w historycznej chwili, a celem jej jest dążenie do jedności narodów poprzez modlitwę i przebaczenie. Pragniemy - według wskazań Świętego Pawła - zmierzać do pojednania między wiernymi Kościoła Greckokatolickiego i Rzymskokatolickiego ${ }^{48}$ ".

W innym miejscu czytamy:

„Drodzy Bracia i Siostry w Chrystusie! Sprawując Najświętszą Eucharystię, w czasie Kongresu Eucharystycznego w Warszawie (19 czerwca) i we Lwowie (26 czerwca), kierować będziemy nasze modlitwy do Boga Wszechmogącego. Zanim to się stanie, spełnijmy święty obowiązek, o którym tak mówi Chrystus: «Jeżeli więc przyniesiesz dar swój przed ołtarz i tam wspomnisz, że brat twój ma coś przeciw tobie, zostaw tam dar swój przed ołtarzem, a najpierw idź i pojednaj się z bratem swoim! Potem przyjdź

\footnotetext{
${ }^{46}$ Ibidem, s. 118.

${ }^{47}$ List biskupów greckokatolickich Ukrainy i rzymskokatolickich Polski z okazji aktu wzajemnego przebaczenia i pojednania, [w:] https://opoka.org.pl/biblioteka/W/WE/kep/list_ukraina_pl_18062005. html [dostęp: 27.09.2021].

${ }^{48}$ Ibidem.
} 
i dar swój ofiaruj» (Mt 5, 23-24). Darem, który przynosimy jest pragnienie spełnienia woli naszego Pana, aby «wszyscy byli jedno»"49.

Doświadczenie przebaczenia ewangelicznego widzimy też w innym fragmencie listu. Jest to swoista parafraza modlitwy Ojcze nasz:

„Wznieśmy się ponad polityczne poglądy i historyczne zaszłości, ponad nasze kościelne obrządki, nawet ponad naszą narodowość - ukraińską i polską. Pamiętajmy przede wszystkim, że jesteśmy dziećmi Boga. Zwróćmy się do naszego Ojca: «Przebacz nam nasze winy, jako i my odpuszczamy naszym winowajcom». Aby nasza modlitwa była ze wszech miar owocna, powiedzmy wobec siebie słowa: «Przebaczamy i prosimy o przebaczenie»»"${ }^{" 50}$.

W dokumencie odnajdujemy wyraźne nawiązanie do dokonań Jana Pawła II. Obaj autorzy tego listu przywołują pamięć o tym, w jaki sposób papież interpretował ideę przebaczenia. Oczywiście jest ona zgodna z tym, co obaj biskupi napisali na ten temat. Śmierć papieża Jana Pawła II 2 kwietnia 2005 roku nakazywała biskupom kontynuować Jego dzieło. Obaj biskupi zwrócili uwagę na to, co łączy oba narody w sposób fundamentalny, niezależny od konfliktów. Podkreśli, że jest to:

„[...] dziedzictwo tej samej wiary, wspólnota chrztu świętego, przez który zostaliśmy wszczepieni niezależnie od przynależności narodowej w śmierć i chwalebne Zmartwychwstanie naszego Pana. Już ponad tysiąc lat temu nasze narody otworzyły się na Chrystusa i Jego Ewangelię, a chrześcijaństwo zaczęło formować naszą kulturę i narodową tożsamość. Wiara w Chrystusa Zmartwychwstałego pomagała nam przetrwać trudny czas wojen, zniewolenia. Niosła nadzieję, że również nasze narody zmartwychwstaną do życia w wolności"’51.

Ta tradycja religijna jest w ich rozumieniu wspólna mimo różnic w procesie inkulturacji w chrześcijaństwo obu narodów. Biskupi ten proces ujęli w następujący sposób:

„Chrześcijaństwo przyszło do Polski z łacińskiej Europy, a na ziemiach ukraińskich wyrosło z tradycji bizantyjskiej. To nas wyróżniało, a niekiedy mogło stawać się przeszkodą w naszych wzajemnych stosunkach; szczególnie wtedy, kiedy nie podejmowano trudu wzajemnego zbliżenia. Często wzajemne różnice bywały też sztucznie wyolbrzymiane przez próbujących nas poróżnić nieprzyjaznych sąsiadów, albo rozniecane przez wewnętrzne spory polityczne. Były przecież w naszej historii okresy, kiedy doświad-

\footnotetext{
${ }^{49}$ Ibidem.

${ }^{50}$ Ibidem.

${ }^{51}$ Ibidem.
} 
czaliśmy wspólnoty losu, szliśmy tą samą drogą, przechodziliśmy razem niejedną próbę, wzajemnie korzystając z duchowych dóbr, czerpiąc z naszej chrześcijańskiej wspólnoty siłę trwania i nadziei" 52 .

Wyrazem tej chrześcijańskiej nadziei dla obu narodów ma być doświadczenie XX wieku. Biskupi jako przykład wskazali krach systemów totalitarnych, Sobór Watykański II oraz ideę jedności europejskiej. Lecz najważniejszym wspólnym doświadczeniem historycznym obu wspólnot narodowych, które nakazuje im konieczność przebaczenia ma być świadectwo wierności Ewangelii. W dramatycznym tonie prosili Polaków i Ukraińców: „W ubiegłym stuleciu nasze narody złożyły świadectwa wierności okupionej śmiercią! Krew przelana przez męczenników wzywa nas do miłości, przyjaciół i wrogów, i woła: «Pojednajcie się!»" ${ }^{33}$

Huzar i Michalik dokonali również podsumowania dotychczasowych wysiłków Kościoła katolickiego mających na celu pojednanie polsko-ukraińskie. Wskazano najważniejsze jego etapy: spotkanie 22 maja 1945 roku kardynała Augusta Hlonda, Prymasa Polski, z biskupem Iwanem Buczko w Papieskim Kolegium Świętego Jozafata w Rzymie; spotkanie 8 i 17 października 1987 roku episkopatów rzymskokatolickiego z Polski i greckokatolickiego; uroczyści milenijne na Jasnej Górze w 1988 roku; jubileusz 2000 lat chrześcijaństwa; wizyta Jana Pawła II w 2001 roku na Ukrainie; poparcie pomarańczowej rewolucji z 2004 roku na Ukrainie ${ }^{54}$. Przypomnieli również podobny akt przebaczenia, który dokonał się między Niemcami i Polakami w 1965 roku dzięki orędziu biskupów polskich do biskupów niemieckich ${ }^{55}$.

\section{0. rocznica tragedii wołyńskiej}

Następna deklaracja pojednawcza obydwu narodów pojawiła się 28 czerwca 2013 roku w związku z 70. rocznicą zbrodni wołyńskiej. Ogłosili ją w Warszawie arcybiskup większy kijowsko-halicki Światosław Szewczuk, arcybiskup Józef Michalik - przewodniczący Konferencji Episkopatu Polski, arcybiskup Mieczysław Mokrzycki - przewodniczący Konferencji Biskupów Ukrainy (łacińskich) oraz Jan Martyniak, arcybiskup greckokatolickiej metropolii przemysko-warszawskiej ${ }^{56}$.

${ }^{52}$ Ibidem.

${ }^{53}$ Ibidem.

${ }^{54}$ Zob. M. Melnyk, Pojednanie polsko-ukraińskie..., op.cit., ss. 87-88.

${ }^{55}$ Zob. Wspólne oświadczenie Konferencji Episkopatów Polski i Niemiec z okazji 40. rocznicy wymiany listów między oboma episkopatami w roku 1965, [w:] http://opoka.org.pl/biblioteka/W/WE/ kep/pl_niemcy_20050924.html [dostęp: 12.12.2015].

${ }^{56}$ Zob. Wspólna deklaracja o pojednaniu polsko-ukraińskim z okazji 70-lecia rocznicy zbrodni na Wotyniu, „Перемиські Архиєпархіяльні Відомості” 2017, nr 42, ss. 354-363. 
Dokument ten zawiera wiele wcześniej podejmowanych wątków. Jego autorzy odnoszą się między innymi do konfliktu polsko-ukraińskiego w latach 1943-1944, do którego nawiązują za pośrednictwem inicjujących tekst słów pochodzących z listu Jana Pawła II (2003): „Niech dzięki oczyszczeniu pamięci historycznej wszyscy będą gotowi stawiać wyżej to, co jednoczy, niż to, co dzieli" ‘57. Tym samym można odnieść wrażenie, że deklaracja z 2013 roku ma być kontynuacją ówczesnego nauczania papieskiego, jego rozwinięciem oraz podsumowaniem dziesięcioletnich starań na rzecz pogłębienia dialogu polsko-ukraińskiego. Najważniejszym elementem deklaracji jest oddanie hołdu pomordowanym Polakom na Wołyniu w 1943 roku. Ich śmierć określono jako zbrodnię powstałą w wyniku czystek etnicznych inspirowanych nacjonalizmem i szowinizmem. Pamięci o ich tragicznej śmierci miała towarzyszyć modlitwa: „[...] o odpuszczenie grzechów i przebaczenie, a także o łaskę stawania w prawdzie wobec Boga i ludzi" ${ }^{58}$. Miała być to więc pamięć oczyszczająca i wyzwalająca. Jak czytamy, jej efektem miały być:

„[...] dalsze kroki na drodze do braterskiego zbliżenia, które jest niemożliwe bez szczerego pojednania. Zachęca nas także do tego obchodzony w tym roku jubileusz 1025-lecia Chrztu Rusi oraz pierwszy rok przygotowań do obchodów 1050-lecia Chrztu Polski. A przecież ochrzczony człowiek i naród przyjmuje nie tylko odpuszczenie grzechów i otrzymuje nadzieję zbawienia, ale także gotowość życia Ewangelią Jezusa Chrystusa z jej nakazem przebaczania win. Jesteśmy świadomi, że tylko prawda może nas wyzwolić (por. J 8, 32); prawda, która niczego nie upiększa i nie pomija, która niczego nie przemilcza, ale prowadzi do przebaczenia i darowania win" ${ }^{\circ 9}$.

Biskupi wezwali do prowadzenia rzetelnych badań naukowych nad tragedią wołyńską:

„Obiektywne poznanie faktów oraz ukazanie rozmiarów tragedii i dramatów przeszłości staje się dzisiaj pilną sprawą historyków i specjalistów, bo tylko poznanie prawdy historycznej wyciszyć może narosłe wokół tej sprawy emocje. Apelujemy więc do polskich i ukraińskich naukowców o dalsze badania oparte na źródłach i o współdziałanie w wyjaśnianiu okoliczności tych przerażających zbrodni, jak również sporządzenie listy imion wszystkich, którzy ucierpieli”"60.

Autorzy deklaracji przypomnieli jej czytelnikom najważniejsze fakty z przeszłości, które wskazywały na stałe wysiłki podejmowane przez Kościół katolicki

\footnotetext{
${ }^{57}$ Ibidem, s. 354.

${ }^{58}$ Ibidem.

${ }^{59}$ Ibidem, s. 356.

${ }^{60}$ Ibidem, s. 358.
} 
w celu pojednania polsko-ukraińskiego. Sa to wydarzenia wymienione w innych dokumentach, tj. spotkanie biskupów w październiku 1987 roku w Rzymie, uroczystości milenijne na Jasnej Górze w 1988 roku, wizyta Jana Pawła II na Ukrainie w 2001 roku. Ten schemat opisu wskazuje, że wytworzył się już stały element redagowania katolickich deklaracji pojednawczych. Można sądzić, że następna będzie sformułowana podobnie. $\mathrm{W}$ dokumencie kilkakrotnie odniesiono się do przyszłości, kreśląc pozytywną wizję relacji polsko-ukraińskich. Jej potencjalna realizacja warunkowana jest wzajemnym przebaczeniem. Biskupi tak o tym pisali:

„[...] bez wzajemnego pojednania nasz Kościół nie byłby wiarygodny w wypełnianiu swej ewangelicznej misji, a nasze narody nie będą miały perspektywy współpracy i rozwoju w płaszczyźnie tak religijnej, jak i politycznej. Uważamy też, że współpraca wolnej Polski z wolną Ukrainą jest niezbędna, by w tej części Europy panował pokój, ludzie cieszyli się wolnością religijną, a prawa człowieka nie były zagrożone. Widzimy też potrzebę wspólnego świadectwa chrześcijan z Polski i Ukrainy w jednoczącej się Europie. Wspólnie stajemy w obliczu wyzwań, jakie stwarza sekularyzacja i próba organizacji życia «jakby Bóg nie istniał». Jesteśmy częścią historii Bożej miłości i - zgodnie z zachętą Ojca Świętego Franciszka - powinniśmy być ogniwem tej miłości w świecie. Kościoły, które doświadczyły męczeństwa, mają szczególne prawo do przypominania Europie o jej chrześcijańskich korzeniach"61.

Jak widzimy, wzajemne przebaczanie jest traktowane jako warunek skutecznej ewangelizacji. I, co więcej, biskupi obu obrządków katolickich stawiają pojednanym ze sobą Polakom i Ukraińcom zadanie ewangelizacji Europy! Wdaje mi się, że jest to myśl godna podkreślenia. Biskupi bowiem powiązali ze sobą ściśle dwa rodzaje działań i celów. Ewangelizacja jest w tej relacji czymś nadrzędnym. Tragizm relacji polsko-ukraińskich z czasów II wojny światowej nie może położyć się cieniem na przyszłości obu narodów predysponowanych do niesienia Ewangelii. Biskupi są zatem pewni, że oba narody wniosą w ten sposób istotny wkład w dzieło zjednoczenia Europy. Patrząc z tej perspektywy na przyszłe - „pojednane” - relacje polsko-ukraińskie, biskupi dostrzegli w nich wymiar ekumeniczny. Tak o tym pisali:

„Ślemy też braterskie pozdrowienia Braciom Prawosławnym, wierząc, że proces wzajemnego pojednania uzdrowi rany, które są przeszkodą nie tylko w harmonijnym współżyciu narodów, ale i w szczerym dążeniu do jedności Chrystusowego Kościoła”².

\footnotetext{
${ }^{61}$ Ibidem, s. 360.

${ }^{62}$ Ibidem.
} 
To krótkie zadanie posiada w sobie spory potencjał. Wyzwolenie obu narodów z nienawiści i uprzedzeń wynikających z bolesnej pamięci o przeszłości ma bowiem stanowić ważny element dialogu ekumenicznego ${ }^{63}$.

\section{Deklaracja pojednawcza 2015 roku}

Dnia 9 czerwca 2015 roku pojawiła się następna deklaracja pojednawcza. Ogłoszona została w Warszawie w czasie wizyty arcybiskupa Światosława Szewczuka, której program obejmował cały szereg spotkań. Najważniejszym z nich była narada przedstawicieli Kościoła katolickiego w Polsce i na Ukrainie w Prezydium Episkopatu Polski. Do spotkania doszło z inicjatywy arcybiskupa Szewczuka. W spotkaniu tym uczestniczyli między innymi: Przewodniczący Konferencji Episkopatu Polski arcybiskup Stanisław Gądecki, zwierzchnik Ukraińskiego Kościoła Greckokatolickiego arcybiskup Światosław Szewczuk, przewodniczący Konferencji Biskupów Rzymskokatolickich Ukrainy arcybiskup Mieczysław Mokrzycki oraz metropolita przemysko-warszawski arcybiskup Jan Martyniak, arcybiskup Marek Jędraszewski, zastępca przewodniczącego Konferencji Episkopatu Polski, bp Marian Rojek, przewodniczący Zespołu ds. Kontaktów z Przedstawicielami Kościoła Greckokatolickiego na Ukrainie. Na jego zakończenie wydano komunikat ${ }^{64}$. Dokument zawiera kilka powiązanych ze sobą problemów. Przede wszystkim przypomina o dziesiątej rocznicy wspólnego listu pasterskiego z okazji aktu wzajemnego przebaczenia i pojednania biskupów greckokatolickich Ukrainy i rzymskokatolickich Polski. Czytamy w nim:

„Pragniemy bardzo, aby dzieło pojednania narodów - polskiego i ukraińskiego - było kontynuowane poprzez konkretną współpracę, wzajemny szacunek, porozumienie i wsparcie między przedstawicielami naszych narodów i Kościołów, aby w ten sposób dawać świadectwo jedności w różnorodności i odpowiedzieć na ekspansję sekularyzmu i wojskową agresję idącą ze Wschodu"65.

W porównaniu z wcześniejszymi tego typu dokumentami pojawiły się nowe wątki. Obecnie biskupi podkreśli znaczenie zespołu do wzajemnych kontaktów

${ }^{63}$ Zob. List patriarchy Filareta z okazji 70-lecia tragedii wotyńskiej, [w:] catholicnews.org.ua /zvernennya-patriarha-kiyivskogo-i-vsiieyi-rusi-ukrayini-filareta-z-nagodi-70-h-rokovin-masovih [dostęp: 03.10.2021].

${ }^{64}$ Zob. Komunikat ze wspólnego spotkania przedstawicieli Kościoła katolickiego w Polsce i na Ukrainie, Warszawa 9 czerwca 2015 r., [w:] Перемиські Архиєпархіяльні Відомості 2017, nr 45, ss. 372-374.

${ }^{65}$ Ibidem. 
Kościoła rzymskokatolickiego w Polsce oraz Kościołów greckokatolickiego i rzymskokatolickiego na Ukrainie. Działalność tego forum pozostawała dotąd w cieniu. Czytelnicy komunikatu dowiedzieli się, że ,zespół” wypracował program współpracy między parafiami obu obrządków w Polsce i na Ukrainie, który należy wcielić w życie. Byłby to zatem praktyczny krok zmierzający ku zastosowaniu idei pojednania w praktyce duszpasterskiej. Następnym novum było zwrócenie uwagi na konieczność poprawienia relacji między obu obrządkami w zakresie właściwego uregulowania kwestii własności obiektów sakralnych. Jednak domyślności czytelników komunikatu pozostawiono problem dokładnego zrozumienia tego postulatu. W tym celu należy zwrócić uwagę na wypowiedź metropolity lwowskiego obrządku rzymskokatolickiego arcybiskupa Mieczysława Mokrzyckiego, który w wywiadzie dla telewizji Polonia, udzielonym 29 maja 2017 roku, bardzo krytycznie wypowiedział się na temat relacji z obrządkiem greckokatolickim na Ukrainie, oskarżając wschodnich katolików o nieprawny zabór 23 świątyń łacińskich we Lwowie. Co więcej, arcybiskup Mokrzycki oświadczył, iż wobec braku możliwości porozumienia się z grekokatolikami zwrócił się w tej sprawie do Watykanu ${ }^{66}$.

Oznaczałoby to narastającą frustrację biskupów obrządku łacińskiego w Polsce i na Ukrainie z powodu braku konkretnych rezultatów deklaracji podpisanej w czerwcu 2013 roku. W ten sposób jednak, pierwszy raz od 1987 roku, w katolickich oficjalnych deklaracjach pojednania polsko-ukraińskiego pojawił się problem ich spowolnienia oraz korekty z powodu wartości utylitarnych - międzyobrządkowego sporu o świątynie we Lwowie. Wcześniej wydawało się, że wysiłki biskupów katolickich, mające na celu pojednanie między obu narodami, biegną w nieodwracalnym kierunku, zmierzającym bezustannie ku ostatecznemu pogodzeniu się obu wspólnot na gruncie wartości ewangelicznych ${ }^{67}$.

$\mathrm{W}$ podsumowaniu przeprowadzonej prezentacji deklaracji pojednawczych autorstwa katolickich biskupów z Polski i Ukrainy warto podkreślić cele, które miały one realizować. Religijny wymiar pojednania katolików obrzędu łacińskiego i greckiego miał doprowadzić do dialogu i porozumienia o charakterze narodowym. Połączenie tych dwóch celów było wyraźnie widoczne od 1987 roku. Wspólne modlitwy oraz akty ekspiacyjne i pojednawcze miały zawsze przyczynić się do autentycznego dialogu między obu wspólnotami narodowymi. Co więcej, miało to dopro-

${ }^{66}$ M. Mokrzycki, Wywiad metropolity lwowskiego obrzqdku rzymskokatolickiego abp Mieczystawa Mokrzyckiego dla telewizji Polonia, [w:] https://halopolonia.tvp.pl/31225951/29052017--wywiadz-arcybiskupem-mieczyslawem-mokrzyckim [dostęp: 03.10.2021].

${ }^{67}$ Podobny dokument powstały 22 listopada 2015 r. z okazji 50. rocznicy wspólnego oświadczenia konferencji episkopatów Polski i Niemiec w roku 1965, zob. Wspólne oświadczenie Przewodniczacych Konferencji Episkopatu Niemiec i Polski z okazji 50. rocznicy wymiany listów z 1965 roku, [w:] https:// cdim.pl/2015-11-22-wspolne-oswiadczenie-przewodniczacych-konferencji-episkopatu-niemiec-i-polski,3620 [dostęp: 27.09.2021]. 
wadzić do odkrycia i wymiany doświadczeń duchowych miedzy tradycją chrześcijańskiego Wschodu i Zachodu. Można zatem dostrzec tutaj oddziaływanie idące w drugim kierunku. Pojednane narody miały zrealizować cele misyjne. Pojednanie o charakterze religijnym, wewnątrzkonfesyjnym, które przezwycięża koncentrację na samym sobie ma umożliwić autentyczną ewangelizację. Należy również zauważyć, że formuła połączenia celów religijnych i narodowo-politycznych została skwapliwie wykorzystana przez elity polityczne obu narodów. Jeżeli byśmy chcieli odtworzyć i prześledzić proces rozwoju stosunków politycznych między państwem polskim i ukraińskim po upadku ZSRR, to zauważymy liczne próby przejmowania idei religijnych pojednania polsko-ukraińskiego do celów politycznych. Wysiłki pojednawcze elit politycznych obu narodów są wyraźnie inspirowane aksjologią analizowanych deklaracji. Ich chrześcijański uniwersalizm aksjologiczny jest szczególnie chętnie przejmowany przez polityków ${ }^{68}$. Widać tutaj swoistą pragmatyczną wiarę. Jest ona wyrazem przekonania, że wartości ewangeliczne mają moc sprawczą, która uzdolni Polaków i Ukraińców do przebaczania i zapomnienia bolesnej przeszłości. Na koniec można zapytać - kiedy i w jakich okolicznościach pojawi się nowa deklaracja podobna do tych, które przedstawiliśmy? Kiedy nastapi kres tworzenia tego typu dokumentów? Jeżeli przestaną one powstawać, czy będzie to znaczyło, że nastąpiło pełne pojednanie między obu narodami?

\section{Literatura}

Źródła

Glemp J., Przemówienie podczas spotkania w Kolegium Polskim, „Znak” 1988, nr 4, ss. 29-31.

Glemp J., Przemówienie podczas spotkania w Kolegium św. Jozafata, „Znak” 1988, nr 4, ss. 36-37.

Głódź L.S., Kazanie wygłoszone podczas Mszy Świętej odprawionej w Pawliwce w intencji Polaków pomordowanych na Wotyniu, „Biuletyn Ukrainoznawczy” 2003, nr 9, ss. 116-118.

Jan Paweł II, O przebaczeniu i pojednaniu, Kraków, Wydawnictwo M, 2000, ss. 87. Jan Paweł II, Chrystus droga, prawda i życiem. Pielgrzymka Ojca Świętego na Ukrainę 23-27 czerwca 2001, 2001, Kraków, Wydawnictwo M, 2001, ss. 135 Jan Paweł II, List z okazji 60. rocznicy tragicznych wydarzeń na Wołyniu, „Biuletyn Ukrainoznawczy" 2003, nr 9, s. 9.

${ }^{68}$ Zob. M. Łesiów, M. Melnyk, O Ukrainie..., op.cit., ss. 449-450. 
Jan Paweł II, Przyjmijcie duchowe przesłanie waszych błogosławionych, [w:] https:// opoka.org.pl/biblioteka/W/WP/jan_pawel_ii/homilie/lwow_beatyfikacja_ 26062001.html [dostęp: 27.09.2021].

List biskupów greckokatolickich Ukrainy i rzymskokatolickich Polski z okazji aktu wzajemnego przebaczenia i pojednania, [w:] https://opoka.org.pl/biblioteka/W/ WE/kep/list_ukraina_pl_18062005.html [dostęp:_20.11.2020].

List patriarchy Filareta z okazji 70-lecia tragedii wotyńskiej, [w:] https://catholicnews.org.ua /zvernennya-patriarha-kiyivskogo-i-vsiieyi-rusi-ukrayini-filaretaz-nagodi-70-h-rokovin-masovih [dostęp: 03.10.2021].

Lubacziwśkyj M., Przemówienie podczas spotkania w Kolegium św. Jozafata, „Znak” 1988, nr 4, ss. 32-35.

Metropolita Andrzej Szeptycki. Pisma wybrane, red. M.H. Szeptycka, M. Skórka, Kraków, Społeczny Instytut Wydawniczy Znak, 2000, ss. 435.

Mokrzycki M., Wywiad metropolity lwowskiego obrzadku rzymskokatolickiego abp Mieczysława Mokrzyckiego dla telewizji Polonia, [w:] https://halopolonia.tvp. pl/31225951/29052017--wywiad-z-arcybiskupem-mieczyslawem-mokrzyckim [dostęp: 03.10.2021].

Nie jesteśmy ukrainofilami. Polska myśl polityczna wobec Ukraińców i Ukrainy. Antologia tekstów, red. P. Kowal, J. Ołdakowski, M. Zuchniak, Wrocław, Kolegium Europy Wschodniej im. Jana Nowaka-Jeziorańskiego, 2008, ss. 435.

Wspólna deklaracja o pojednaniu polsko-ukraińskim z okazji 70-lecia rocznicy zbrodni na Wotyniu, „Перемиські Архиєпархіяльні Відомості” 2017, $\mathrm{nr} 42$, ss. 354-363.

Wspólne oświadczenie Konferencji Episkopatów Polski i Niemiec z okazji 40. rocznicy wymiany listów między oboma episkopatami w roku 1965 [w:] http://opoka. org.pl/biblioteka/W/WE/kep/pl_niemcy_20050924.html [dostęp: 12.12.2015].

Wspólne oświadczenie Przewodniczacych Konferencji Episkopatu Niemiec i Polski z okazji 50. rocznicy wymiany listów z 1965 roku, [w:] https://cdim.pl/2015-1122-wspolne-oswiadczenie-przewodniczacych-konferencji-episkopatu-niemieci-polski,3620 [dostęp: 27.09.2021].

Opracowania

Archer M.S., Kultura i sprawczość. Miejsce kultury w teorii społecznej, thum. P. Tomek, Warszawa, Narodowe Centrum Kultury, 2019, ss. 543.

Bachanek G., Elementy idei stowiańskości Zygmunta Szczęsnego Felińskiego a myśl Jana Pawta II, „Warszawskie Studia Teologiczne” 2016, nr 3, ss. 218-231.

Bobrownicka M., Łużny R., Karol Wojtyła - Jan Pawet II w kręgu spraw słowiańskich, [w:] Dzieło chrystianizacji Rusi Kijowskiej i jego konsekwencje w kulturze Europy, 
red. R. Łużny, Lublin, Redakcja Wydawnictw Katolickiego Uniwersytetu Lubelskiego, 1988, ss. 383-416.

Hajowa O., Nauka społeczna metropolity Andrzeja Szeptyckiego w świetle materiatów archiwalnych, [w:] Polska - Ukraina. 1000 lat sqsiedztwa, t. 4, red S. Stępień, Przemyśl, Południowo-Wschodni Instytut Naukowy w Przemyślu, 1998, ss. $273-285$.

Kęsik J., Zaufany komendanta. Biogram polityczny Jana Henryka Józefskiego 18921981, Wrocław, Uniwersytet Wrocławski, 1995, 213 ss.

Komunikat ze wspólnego spotkania przedstawicieli Kościoła katolickiego w Polsce i na Ukrainie, Warszawa 9 czerwca 2015 r., [w:] Перемиські Архиєпархіяльні Відомості 2017, nr 45, ss. 372-374.

Łesiów M., Melnyk M., O Ukrainie. Prawie wszystko!?, Olsztyn, Katedra Aksjologicznych Podstaw Edukacji. Uniwersytet Warmińsko-Mazurski, 2011, 450 ss.

Melnyk M., Problem badań nad dialogiem i pojednaniem polsko-ukraińskim, [w:] W cieniu akcji Wista, red. M. Melnyk, Olsztyn, Instytut Nauk Politycznych Uniwersytetu Warmińsko-Mazurskiego, 2008, ss. 99-120.

Melnyk M., Rola prezydenta Rzeczypospolitej Polskiej Aleksandra Kwaśniewskiego oraz hierarchów Kościoła greckokatolickiego w pojednaniu i dialogu polskoukraińskim. Zarys problematyki, „Biuletyn Ukrainoznawczy“ 2003, nr 9, ss. 83-98.

Melnyk M., Pojednanie polsko-ukraińskie. Deklaracja Kościołów katolickich Polski i Ukrainy z 19 IV 2005, „Przegląd Powszechny” 2005, nr 12, ss. 87-102.

Melnyk M., Rola Kościoła greckokatolickiego $w$ dialogu i pojednaniu polskoukraińskim po 2001 roku, red. M. Giedrojć, M. Mieczkowska, J. Mieczkowski, Szczecin, Wydawnictwo Uniwersytetu Szczecińskiego, 2005, ss. 145-156.

Melnyk M., Millenium chrztu Rusi Kijowskiej w procesie pojednania polsko-ukraińskiego, [w:] Polacyi Ukraincy. Komunikacja-dialog-pojednanie, red. M. Melnyk, Kraków, Collegium Columbinum, 2021, ss. 99-113.

Mosty nadziei. Jagiellońskie inspiracje dialogu międzykulturowego, red. L. Korporowicz, S. Jaskóła, M. Stefanowic, P. Plichta, Kraków, Biblioteka Jagiellońska, 2016, 295 ss.

Mróz M., Katolicyzm na pograniczu. Kościót katolicki wobec kwestii ukraińskiej i białoruskiej w Polsce w latach 1918-1925, Toruń, Wydawnictwo Adam Marszałek, 2003, 313 ss.

O wolność i sprawiedliwość. Chrześcijańska Europa między wiara i rewolucja, red. U. Cierniak, N. Morawiec, A. Bańczyk, Częstochowa, Wydawca: Instytut Filologii Obcych Uniwersytetu Humanistyczno-Przyrodniczego im. Jana Długosza w Częstochowie, 2018, 666 ss.

Serczyk W.A., Historia Ukrainy, Wrocław, Warszawa, Kraków, Zakład Narodowy im. Ossolińskich, 1990, ss. 518. 
Stępień S., Wysitki Polaków i Ukraińców na rzecz wzajemnego porozumienia w latach 1918-1939, „Warszawskie Zeszyty Ukrainoznawcze” 1994, nr 2, ss. 96-104.

\section{References}

Primary sources

Glemp J., Przemówienie podczas spotkania w Kolegium Polskim [Speech at the Meeting at the Polish College], "Znak" 1988, no. 4, pp. 29-31.

Glemp J., Przemówienie podczas spotkania w Kolegium św. Jozafata [Speech During the Meeting at the College of St. Josaphat], "Znak" 1988, no. 4, pp. 36-37.

Głódź L.S., Kazanie wygloszone podczas Mszy Świętej odprawionej w Pawliwce w intencji Polaków pomordowanych na Wotyniu [Sermon Delivered during the Holy Mass Celebrated in Pawliwka for Poles Murdered in Volhynia], "Biuletyn Ukrainoznawczy" 2003, no. 9, pp. 116-118.

Jan Paweł II, O przebaczeniu і ројеdnaniu [About Forgiveness and Reconciliation], Kraków, Wydawnictwo M, 2000, 87 pp.

Jan Paweł II, Chrystus droga, prawda i życiem. Pielgrzymka Ojca Świętego na Ukraine 23-27 czerwca 2001 [Christ: the Way, the Truth and the Life. The Holy Father's Pilgrimage to Ukraine, June 23-27], 2001, Kraków, Wydawnictwo M, 2001, 135 pp.

Jan Paweł II, List z okazji 60. rocznicy tragicznych wydarzeń na Wołyniu [Letter on the Occasion of the $60^{\text {th }}$ Anniversary of the Tragic Events in Volhynia], "Biuletyn Ukrainoznawczy" 2003, no. 9, 9 pp.

Jan Paweł II, Przyjmijcie duchowe przesłanie waszych błogosławionych, [Receive the Spiritual Message of your Blessed], Lviv. Available at: https://opoka.org. pl/biblioteka/W/WP/jan_pawel_ii/homilie/lwow_beatyfikacja_26062001.html [accessed: 27.09.2021].

Komunikat ze wspólnego spotkania przedstawicieli Kościoła katolickiego w Polsce i na Ukrainie, Warszawa 9 czerwca 2015 r. [Communique of the Joint Meeting ofRepresentatives of the Catholic Church in Poland and Ukraine, Warszawa, 9 June 2015], "Peremyski Archyjeparchijalni Widomosti" 2017, nr 45, pp. 372-374.

Kowal P., Ołdakowski J., Zuchniak M. (Eds.), Nie jesteśmy ukrainofilami. Polska myśl polityczna wobec Ukraińców i Ukrainy. Antologia tekstów [We Are Not Ukrainianphiles. Polish Political Thought on Ukrainians and Ukraine. An Anthology], Wrocław, Kolegium Europy Wschodniej im. Jana Nowaka-Jeziorańskiego, 2008, 435 pp. 
List biskupów greckokatolickich Ukrainy i rzymskokatolickich Polski z okazji aktu wzajemnego przebaczenia i pojednania [Letter from Greek Catholic Bishops of Ukraine and Roman Catholic Bishops of Poland on the Occasion of the Act of Mutual Forgiveness and Reconciliation]. Available at: https://opoka.org.pl/biblioteka/W/WE/kep/list_ukraina_pl_18062005.html [accessed:_27.09.2021].

List patriarchy Filareta $z$ okazji 70-lecia tragedii wotyńskiej [Letter from the Patriarch Filaret on the $70^{\text {th }}$ Anniversary of the Volyn Tragedy]. Available at: https:/catholicnews.org.ua /zvernennya-patriarha-kiyivskogo-i-vsiieyi-rusiukrayini-filareta-z-nagodi-70-h-rokovin-masovih [accessed: 03.10.2021].

Lubacziwśkyj M., Przemówienie podczas spotkania $w$ Kolegium św. Jozafata [Speech During the Meeting at the College of St. Josaphat], "Znak" 1988, no. 4, pp. 32-35.

Mokrzycki M., Wywiad metropolity lwowskiego obrządku rzymskokatolickiego abp Mieczysława Mokrzyckiego dla telewizji Polonia [Interview with Archbishop Mieczyslaw Mokrzycki, Metropolitan of Lvovian Roman Catholic Rite for Polonia Television]. Available at: https://halopolonia.tvp. pl/31225951/29052017--wywiad-z-arcybiskupem-mieczyslawem-mokrzyckim [accessed: 03.10.2021].

Szeptycka M.H., Skórka M. (Eds.), Metropolita Andrzej Szeptycki. Pisma wybrane [Metropolitan Andrey Sheptytsky. Selected Works], Kraków, Społeczny Instytut Wydawniczy Znak, 2000, 435 pp.

Wspólna deklaracja o pojednaniu polsko-ukraińskim z okazji 70-lecia rocznicy zbrodni na Wotyniu [Joint Declaration on Polish-Ukrainian Reconciliation on the Occasion of the $70^{\text {th }}$ Anniversary of the Crime in Volhynia], "Peremyski Archyjeparchijalni Widomosti" 2017, no. 42, pp. 354-363.

Wspólne oświadczenie Konferencji Episkopatów Polski i Niemiec z okazji 40. rocznicy wymiany listów między oboma episkopatami w roku 1965 [Joint Statement by Polish and German Episcopal Conferences on the Occasion of the $40^{\text {th }}$ Anniversary of the Letters Exchange Between the Two Episcopates in 1965]. Available at: http://opoka.org.pl/biblioteka/W/WE/kep/pl_niemcy_20050924. html [accessed: 12.12.2015].

Wspólne oświadczenie Przewodniczqcych Konferencji Episkopatu Niemiec i Polski z okazji 50. rocznicy wymiany listów z 1965 roku [Joint Statement by Polish and German Presidents of the Episcopal Conferences on the Occasion of the $50^{\text {th }}$ Anniversary of the Letters Exchange Between the Two Episcopates in 1965]. Available at: https://cdim.p1/2015-11-22-wspolne-oswiadczenie-przewodniczacych-konferencji-episkopatu-niemiec-i-polski,3620 [accessed: 27.09.2021]. 
Secondary sources

Archer M.S., Kultura i sprawczość. Miejsce kultury w teorii spotecznej [Culture and Agency: The Place of Culture in the Social Theory], trans. P. Tomek, Warszawa, Narodowe Centrum Kultury, 2019, 543 pp.

Bachanek G., Elementy idei słowiańskości Zygmunta Szczęsnego Felińskiego a myśl Jana Pawta II, [Elements of the Slavic Idea in the Thought of Zygmunt Szczęsny Feliński and the Thought of John Paul II] "Warszawskie Studia Teologiczne" 2016, no. 3, pp. 218-231.

Bobrownicka M., Łużny R., Karol Wojtyła - Jan Pawet II w kregu spraw stowiańskich [Karol Wojtyła-John Paul II in the Circle of Slavic Affairs], [in:] Dzieło chrystianizacji Rusi Kijowskiej i jego konsekwencje $w$ kulturze Europy [Christianisation of Kievan Rus and Its Consequences in the Culture of Europe], R. Łużny (Ed.) Lublin, Redakcja Wydawnictw Katolickiego Uniwersytetu Lubelskiego, 1988, pp. 383-416.

Cierniak U., Morawiec N., Bańczyk A. (Eds.), O wolność i sprawiedliwość. Chrześcijańska Europa między wiarq i rewolucja [About Freedom and Justice. Christian Europe Between Faith and Revolution], Czestochowa, Instytut Filologii Obcych Uniwersytetu Humanistyczno-Przyrodniczego im. Jana Długosza w Częstochowie, Polskie Towarzystwo Historyczne, Oddział w Częstochowie, 2018, $666 \mathrm{pp}$.

Hajowa O., Nauka społeczna metropolity Andrzeja Szeptyckiego wświetle materiałów archiwalnych [Social Sciences in the Thought of Archbishop Andrey Sheptytsky in the Light of Archival Materials], [in:] Polska - Ukraina. 1000 lat sqsiedztwa [Poland - Ukraine. 1000 Years of Neighbourliness] vol. 4, S. Stępień (Ed.), Przemyśl, Południowo-Wschodni Instytut Naukowy w Przemyślu, 1998, pp. 273285.

Kęsik J., Zaufany komendanta. Biogram polityczny Jana Henryka Józefskiego 18921981 [Trusted Commander. Political Biography of Jan Henryk Józefski 18921981], Wrocław, Uniwersytet Wrocławski, 1995, 213 pp.

Korporowicz L., Jaskóła S., Stefanowic M., Plichta P. (Eds.), Mosty nadziei. Jagiellońskie inspiracje dialogu międzykulturowego [Bridges of Hope. Jagiellonian Inspirations of Intercultural Dialogue], Kraków, Biblioteka Jagiellońska, 2016, 295 pp.

Łesiów M., Melnyk M., O Ukrainie. Prawie wszystko!? [About Ukraine. Almost Everything!?], Olsztyn, KatedraAksjologicznych Podstaw Edukacji. Uniwersytet Warmińsko-Mazurski, 2011, 450 pp.

Melnyk M., Problem badań nad dialogiem i pojednaniem polsko-ukraińskim [The Problem in the Research on Polish-Ukrainian Dialogue and Reconciliation], 
[in:] W cieniu akcji Wista [In the Shadow of the Vistula Action], M. Melnyk (Ed.), Olsztyn, Instytut Nauk Politycznych Uniwersytetu Warmińsko-Mazurskiego, 2008, pp. 99-120.

Melnyk M., Rola prezydenta Rzeczypospolitej Polskiej Aleksandra Kwaśniewskiego oraz hierarchów Kościoła greckokatolickiego w pojednaniu i dialogu polskoukrainskim. Zarys problematyki [The Role of the President of the Republic of Poland, Aleksander Kwasniewski, and the Hierarchs of the Greek Catholic Church in Polish-Ukrainian Reconciliation and Dialogue. The Outline], "Biuletyn Ukrainoznawczy" 2003, no. 9, pp. 83-98.

Melnyk M., Pojednanie polsko-ukraińskie. Deklaracja Kościołów katolickich Polski $i$ Ukrainy z 19 IV 2005 [Polish-Ukrainian Reconciliation. Declaration of the Catholic Churches of Poland and Ukraine of April 19, 2005], "Przegląd Powszechny" 2005, no. 12, pp. 87-102.

Melnyk M., Rola Kościoła greckokatolickiego $w$ dialogu i pojednaniu polskoukrainskim po 2001 roku [The Role of the Greek Catholic Church in PolishUkrainian Dialogue and Reconciliation after 2001], [in:] Polityka i mniejszości narodowe na pograniczach [Politics and National Minorities on the Frontier], M. Giedrojć, M. Mieczkowska, J. Mieczkowski (Eds.), Szczecin, Wydawnictwo Uniwersytetu Szczecińskiego, 2005, pp. 145-156.

Melnyk M., Millennium chrztu Rusi Kijowskiej w procesie pojednania polsko-ukraińskiego [The Millennium of the Baptism of Kievan Rus in the Process of Polish-Ukrainian Reconciliation], [in:] Polacy i Ukraincy. Komunikacja dialog - pojednanie [Poles and Ukrainians. Communication - Dialogue Reconciliation], M. Melnyk (Ed.), Kraków, Collegium Columbinum, 2021, pp. 99-113.

Mróz M., Katolicyzm na pograniczu. Kościót katolicki wobec kwestii ukraińskiej i białoruskiej w Polsce w latach 1918-1925 [Frontier Catholicism. The Catholic Church Towards Ukrainian and Belorussian Issues in Poland in the Years 19181925], Toruń, Wydawnictwo Adam Marszałek, 2003, 313 pp.

Serczyk W.A., Historia Ukrainy [History of Ukraine], Wrocław, Warszawa, Kraków, Zakład Narodowy im. Ossolińskich, 1990, 518 pp.

Stępień S., Wysitki Polaków i Ukraińców na rzecz wzajemnego porozumienia w latach 1918-1939 [Efforts of Poles and Ukrainians for Mutual Understanding in 1918-1939], "Warszawskie Zeszyty Ukrainoznawcze" 1994, no. 2, pp. 96-104. 